\title{
Learners' perceptions of the effectiveness of using self- reflection to understand English literary texts: towards an autonomous learning approach in Libya
}

\author{
Hana El-Badri \\ University of Benghazi, Benghazi, Libya \\ Fatma Abu-baker \\ University of Glasgow, Glasgow, UK
}

\begin{abstract}
Teaching learners to reflect on their work has been widely researched within languagelearning contexts in higher education. Research has revealed that self-reflection leads to both development in learners' reading comprehension and lecturers being enabled to write more meaningful corrective feedback on learners' assignments. Using a collaborative teaching approach at Benghazi university, this research evaluated the effectiveness of using a self-reflection worksheet for understanding short stories based on the perspectives of 19 tertiary Libyan learners and the course lecturers' feedback.
\end{abstract}

The research process involved the learners first reading a short story and answering text comprehension questions and a reflection question in which they commented on their understanding. They were then introduced to the self-reflection worksheet and advised how to use it in their second reading of the same story. This self-reflection worksheet included a section where students added reflections on their understanding following the second reading, supported by the worksheet. Content analysis was used for the qualitative data that investigated the learners' reflection after their first and second reading. It was also used for staff feedback on the learners' reflections.

The findings show the usefulness of using the self-reflection worksheet in supporting the learners' meaning understanding. It also helped them make positive changes during their second reading of the story. Evidence suggests that using worksheets for reading literary 
texts is effective in improving levels of reading comprehension. Implications and suggestions for effective teaching practice and future research are provided in this paper.

Keywords: self-reflection; self-reliance; learner autonomy.

\section{Introduction}

The epistemological views of social constructivists prioritise the active role of learners. Social constructivists consider learning to be an-ongoing process in which teachers use classroom activities and reflection tools to achieve their learning targets. For Schack (1994), reflecting on learning provides learners with 'feedback upon the completion and guides their learning along the way' (p.39). Accordingly, the importance of relating selfreflection to learning development should be apparent to language instructors (Cheng and Fox, 2017; Everhard and Murphy, 2015).

For Roberts (2006), learners' ability to reflect on their own work is 'a vital skill in the external world' (p.3). McConnell (2000) also stresses that when learners are actively involved in the process of 'judging their own and others' work', then their learning will be more meaningful than that of passive learners who are considered as 'the objects of others', receiving taught information provided to them by their teacher ( $p .127)$. Considering the use of self-reflection in language learning development, Cheng and Fox stress the following advantages of using portfolios as a tool of self-reflection:

- monitoring how students manage tasks over time;

- reviewing student development and performance;

- examining the nature of different tasks and/or distinguishing situations in which students are most or least successful and;

- $\quad$ assessing performance (p.84).

It can then be argued that reflection on learning contributes to guiding learners to assess their own areas of weakness and strength; it supports their communication skills and 
develops their self-reliance. For such reasons, the effect of self-reflection on learning should be further researched. This investigation therefore concentrates on the effect of self-reflection on the ability to read English literary texts among Libyan university students.

At Libyan universities, instructors in literature use different methods to measure their students' learning, including written tests, text summaries, homework exercises, oral presentations, and question-and-answer activities. Therefore, Libyan instructors are usually engaged in different assessment activities during their class time (Stiggins, 2001). Moreover, student assessment involves mid-term testing and final exams to assess learners' achievement (Gronlund and Linn, 1990). Such tests aim to assess the overall knowledge of learners, but do not contribute to the learning process itself. Researchers, however, argue that restricting assessment to systematic tests can negatively affect the process of language learning because it may bring fear and anxiety. Learners may also be disappointed especially when what they concentrate on is not emphasised in the exam questions (Guskey, 2003; Shaaban, 2005). Hence, learners are required to reflect on their own learning development during the whole learning process.

In spite of the fact that recent reading research emphasises the role of active learning to enhance reading (Applebee et al., 2003), to the researchers' knowledge there is no research investigating the effectiveness of using different strategies for reading in higher education. Therefore, this investigation fills this gap by examining the effectiveness of using a reflective worksheet as a tool to improve university students' reading comprehension. In addition, no research has been conducted to evaluate the effectiveness of learners' self-reflection on reading English literary texts in Libyan universities. Earlier research has rarely focused on student perspectives on the effectiveness of self-reflection, which would provide an insight into the appropriateness of such an approach. Therefore, this research paper sets out to examine the following questions with a group of Libyan university students of English:

1. To what extent did the Libyan students believe that the self-reflection worksheet supported their own understanding of the text?

2. What were the Libyan students' perceived areas of improvement after using the self-reflection worksheet? 


\section{Research methods}

Libyan participants were introduced to the self-reflection sheet as an enhancement activity intended to support their growing understanding and maximise their learning outcomes. The self-reflection worksheet emphasised some areas that the participants were required to develop during their reading by using the prompts included in the self-reflection form (Appendix 1). It was essential to investigate the impact of this enhancement to establish its benefits. Therefore, an action research approach was adopted (Mitchell et al., 2009). Bias and ethical considerations for the worksheet were peer reviewed by staff in the department of Applied Linguistics at Benghazi university prior to the data collection.

\section{Sample}

A sample of 24 undergraduate Libyan learners of English was included, and participants signed consent forms prior to data collection. The participants were all registered in the sixth semester. At this level, learners are required to develop significant self-regulation. From experience, these students study in a traditional teacher-centred context. They have already studied literary modules and passed through an official test system, including midterm and final exams for their courses. Moreover, the participants are not usually required to feed back on the development of their own reading or to reflect on the appropriateness of their linguistic knowledge for the reading of texts in their teacher-centred learning setting. Therefore, the learners' autonomy during the learning process was emphasised in this investigation by utilizing critical reflections.

\section{Procedure}

The participants had already been directly taught courses on reading comprehension and literary analysis during their university life. This ensured that they were able to access the text regardless of their reading abilities and to understand the short story. In other words, through independent reading, they needed to use their strategies and critical skills with the guidance of the self-reflection form to understand the text.

The purpose of the investigation was explained to the students in the first meeting prior to data collection. The task required the learners to read the text entitled The Cask of 
Amontillado by Edgar Allan Poe, which the learners had not studied yet but was part of their curriculum. Learners submitted their answers within a week and reflected on their understanding in the reflection section. The participants were then offered another meeting with the researcher to gain a fuller understanding of the way to use the worksheet. The learners were given another week to revise their answers using the self-reflection sheet. The questions on the text concentrated on the following points:

- Understanding the story.

- Paragraphing.

- Figurative meaning.

- Sequence of events.

The learners' answers after using the worksheet were reviewed by two literature lecturers to find any developments in in learners' responses. Accordingly, the study plan comprised the following stages:

\section{Figure 1: An overview of the study.}

\section{Sampling}

2. First reading and learners' reflection on their understanding

\section{Introducing the learners to the worksheet}

4. Submission of second reading and learners' self reflection

\section{Lecturers' feedback}




\section{Self-reflection worksheet}

The self-reflection worksheet was constructed by the researcher. It aims to help the students understand and use different reading strategies independently. It consists of the following five parts: understanding language and figurative forms, development of events, identifying the characters, overall meaning, and reflection. Each part has a checklist to help the students incorporate different skills and techniques in their reading. The items in the checklists include instructions and examples to support independent reading and understanding. The last part involves the learners' reflection. An overview of the worksheet which included open and closed questions is summarised in Appendix 1.

\section{Data collection}

For ethical considerations and ease of reference, participants were given codes (S1, S2, S3, etc.). Qualitative data from the learners' reflections was collected from the last reflective section. Using content analysis, learners' reflections were categorised using NVIVO software. Moreover, responses to a scaling question in the last reflection section were analysed using a Likert scale. The feedback provided by the staff was retained and related to the students' reflections.

\section{Data analysis}

Content analysis involved organizing the qualitative data into themes. Common themes were checked in both the lecturer's feedback and the learners' reflections. To do so, key words for common themes were identified from the data itself rather than being created by the researcher. Additionally, content analysis involved counting the number of times the students mentioned the areas of understanding, paragraphing, figurative meaning and sequence of events. However, this repetition also involved descriptive analysis in line with the last scaling question. 


\section{Findings}

The 24 participants submitted the two versions of the text comprehension questions. Four participants did not answer or make any changes to the second version. One participant did not submit the worksheet. Accordingly, complete data for analysis was available for only 19 students. In line with the research questions, the collected data provided information about the participants' perspectives on the effectiveness of the self-reflection worksheet, in addition to their perceived areas of improvement based on the difficulties identified and developments made; these were crystalised with the staff feedback.

\section{Participants' perceptions of the worksheet}

Data for the first research question concentrated on how the self-reflection supported the learners' reading. In response to the question, 'How useful did you find the worksheet?', the participants responded using words such as 'the worksheet help me', 'the guidelines remember me', 'I integrate the instructions', and 'I was improving'. These phrases are quoted exactly as used by the participants. It is worth stressing that these phrases appeared with terms including comprehension, irony and figurative uses, story development, cultural background, and theme of the story. The occurrence of these words is categorised, counted and reported in Table 1 below:

Table 1. Perceptions of the usefulness of the worksheet.

\begin{tabular}{|l|l|l|}
\hline Category & Frequency & Percentages \\
\hline Comprehension & 10 & $53 \%$ \\
\hline Language forms & 13 & $70 \%$ \\
\hline Events & 11 & $58 \%$ \\
\hline Text development & 14 & $74 \%$ \\
\hline Cultural content & 12 & $63 \%$ \\
\hline Text meaning & 12 & $63 \%$ \\
\hline
\end{tabular}

The table reveals the usefulness of the self-reflection worksheet. All 19 students reported perceived benefits. 


\section{Perceived areas of improvement}

Participants also reflected on their perceived difficulties in reading the story. These were identified in their responses to the question, 'What difficulties did the worksheet help you to address?'. The participants used phrases such as 'should focused on', 'need to use', 'my main weakness', 'my mistake 'and 'need make revision', which directed the emphasis towards the students' perceived weaknesses.

Staff feedback on the participants' revised answers is also summarised in Appendix 2. Lecturers used expressions such as 'improved', 'developed understanding', 'used the worksheet effectively' and 'corrected'. Such phrases highlight the positive changes the students made in the revised version.

\section{The usefulness of the self-reflection worksheet}

The 19 participants completed the scale question about the usefulness of the worksheet in developing their understanding. The rating was based on a Likert scale ranging from 1 (very unuseful) to 5 (very useful). The majority of students' answers ranged between 4 and 5 (useful and very useful). One participant (S11) responded with a 2 (unuseful), and another student (S10) responded with a 1 (very unuseful) as summarised below:

\section{Table 2. The percentages of the participants' responses}

\begin{tabular}{|l|l|l|}
\hline Scaling & Frequency & Percentage \\
\hline $\mathbf{1}$ & 1 & $5.26 \%$ \\
\hline $\mathbf{2}$ & 1 & $5.26 \%$ \\
\hline $\mathbf{3}$ & 0 & 0 \\
\hline $\mathbf{4}$ & 12 & $63.16 \%$ \\
\hline $\mathbf{5}$ & 5 & $26.32 \%$ \\
\hline
\end{tabular}

Analysis of the data from responses to the reflection question indicates the extent to which participants benefited from the worksheet and is in line with the data collected from their responses to the scale question. The qualitative data below indicates how the participants benefited from the worksheet: 
- Guided my reading in organized way (S5).

- Helped me to identify difficulties and can treat (S7).

- Helped me to understand the structure and other things too (S17).

- It is like steps to use and understand (S12).

- This worksheet helped me to identify irony I thought metaphor first (S9).

Only three participants suggested that some changes should be made to the worksheet. These suggested changes include the following:

- Worksheet need to include more meaning of words (S15).

- This was useful but can be confusing too (S10).

- Better if the sheet have summary to the story (S1).

\section{Discussion and implications}

In line with earlier research findings (Bressoud, 2008; Wirth and Aziz, 2009; Li and Hegelheimer, 2013; Holbrook and Park, 2017), the analysis of the participants' qualitative data shows promising findings. It indicates that the Libyan participants found the selfreflection worksheet useful. Their perceptions indicate positive changes corroborated by the staff feedback.

The lecturers' feedback on the second submission indicated developments in the learners' understanding. The worksheet guided some participants to make major amendments, while others provided minor changes only. The analysis also indicated that the participants were able to identify their specific difficulties in understanding, thus positively impacting upon the reading process.

This research demonstrates benefits of the worksheet in understanding the figurative forms, the cultural content and the events of the story leading to an overall understanding. Additionally, analysis of the learners' data triangulated with the staff feedback revealed changes in and development of the participants' understanding. This suggests that the 
worksheet helped students to identify what to develop and how to develop it during their use of the worksheet.

To enhance further improvements, most of the lecturers' comments on the participants' first drafts focused on the need to improve critical reading (see Appendix 2). This suggests that the worksheet requires enhancement to guide the participants towards their potential in terms of critical reading. A further investigation to determine the appropriateness of critical reading for improving Libyan learners' thinking and the development of their understanding of literary texts is also required.

Besides critical questioning, some participants needed more scaffolding, according to the lecturers' feedback. Providing some scaffolding can enable the participants to develop their learning (Vygotsky, 1987). It may, therefore, be helpful to have directions that refer the participants to resources relating to more challenging aspects of structure and language. In this analysis, figurative language, and more specifically, irony, were found difficult. Such scaffolding would enable them to consolidate their understanding of such forms leading to the development of their understanding of texts.

The data also reveals that some participants were not able to use the worksheet efficiently. It may be more appropriate to introduce Libyan learners at university to more worksheets in order to guide them towards critical reading and shift the learning process towards learner autonomy. Other participants still need more guidance from lecturers to address areas requiring development. This can simply be attributed to the participants' style of learning and to the approach to teaching, which is still lecture based in Libyan higher education. At the university level, however, the participants should be more autonomous and able to reflect on their own learning. The self-reflection worksheet can therefore be used to support appropriate levels of autonomy.

\section{Limitations}

1. Data was available for only 19 students. Drawing conclusions from such a small number in similar contexts of EFL learning would be difficult. Therefore, it is 
recommended that further research should include a greater number of participants for further investigation of the effectiveness of using worksheets to enhance learning autonomy in Libyan higher education learning contexts.

2. It would be more useful for further research to investigate if participants applied their development to subsequent assignments. Researchers need to investigate the quality of changes applied not only to second drafts, but also to evaluate subsequent summative assessments learners would complete.

3. Methods of data collection in this investigation were limited to the worksheet, which included the participants' reflections and the staff feedback. The worksheet could not provide rich information that other methods such as interviews would have provided. However, the worksheet has shown the development of some participants. For example, Student 7 provided some critical questions that guided his/her critical thinking. It also enabled the participant to provide comments that honestly reflect his/her development.

\section{Further research}

Further investigation could use other methods of analysis, such as discourse analysis, to closely assess the development made in the participants' understanding after using the self-reflection worksheet. Discourse analysis would provide more information about the learners' experiences and the impact of the information provided in the worksheet on the learners' overall understanding (McCarthy,1991). Future research could also include a greater number of participants and investigate ongoing uses of the worksheet to support additional benefits with different learning groups.

\section{Conclusions}

Despite its limitations, this study has shown that the Libyan participants had positive perceptions of using the self-reflection worksheet in their reading. It guided them in identifying their difficulties in reading the text independently. It also helped them to address their development. Such preliminary results suggest development in the learning experience of the participants. Moreover, the study is an extended investigation of earlier 
research findings in the traditional learning setting of Libya. However, it would be essential for further research to consider learners' needs in constructing more effective worksheets to support learners' reading.

\section{References}

Applebee, A., Langer, J., Nystrand, M. and Gamoran, A. (2003) 'Discussion-based approaches to developing understanding: classroom instruction and student performance in middle and high school English', American Educational Research Journal, 40(3), pp.685-730. Available at:

https://psycnet.apa.org/doi/10.3102/00028312040003685 (Accessed: 14 September 2021).

Bressoud, D. (2008) 'Launchings: getting students to read', Mathematical Association of America. Available at:

https://www.maa.org/external archive/columns/launchings/launchings 5 08.html\#k ey1 (Accessed: 13 September 2021).

Cheng, L. and Fox, J. (2015) Assessment in the language classroom. London: Palgrave.

Collins, J. and O'Brien, N. (2003) The Greenwood dictionary of education. Westport, CT: Greenwood Press.

Crooks, T. (2001) 'The validity of formative assessment', The British Educational Research Association Annual Conference. University of Leeds, Leeds 13-15 September. Retrieved February 2020.

Everhard, C. and Murphy, L. (2015) Assessment and autonomy in language learning. Basingstoke: Palgrave Macmillan

Gronlund, N.E. and Linn, R.L. (1990) Measurement and evaluation in teaching. $6^{\text {th }}$ edn. New York: Macmillan. 
Guskey, T. (2003) 'How classroom assessment improves learning', Educational Leadership, 60(5), pp.6-11. Available at: https://www.ascd.org/el/articles/howclassroom-assessments-improve-learning (Accessed: 13 September 2021).

Holbrook, G. and Park, V. (2017) 'Student perceptions of the effectiveness of self-editing on their writing: towards a self-regulated approach', Journal of Learning Development in Higher Education, 0(12). Available at: https://doi.org/10.47408/ildhe.v0i12.425 (Accessed: 13 September 2021).

Li, Z. and Hegelheimer, V. (2013) 'Mobile-assisted grammar exercises: effects on selfediting in L2 writing', Language Learning \& Technology, 17(3), pp.135-156. Available at: http://dx.doi.org/10125/44343 (Accessed: 13 September 2021).

McCarthy, M. (1991) Discourse analysis for language teachers. Cambridge: Cambridge University Press.

McConnell, D. (2000) Implementing computer supported cooperative learning. London: Kogan Page.

Mitchell, S.M., Reilly, R.C. and Logue, M.E. (2009) 'Benefits of collaborative action research for the beginning teacher', Teaching and Teacher Education, 25(2), pp. 344-349. Available at: https://doi.org/10.1016/..tate.2008.06.008 (Accessed: 14 September 2021).

Roberts, T.S. (2006) Self, peer and group assessment in E-Learning. London: Information Science publishing.

Shaaban, K. (2005) 'Assessment of young learners', English Teaching Forum, 43(1), pp.34-40. Available at: https://americanenglish.state.gov/files/ae/resource files/0543-1-g.pdf (Accessed: 13 September 2021). 
Schack GD. (1994) 'Authentic assessment procedures for secondary students' original research', The Journal of Secondary Gifted Education,6(1), pp.38-43.

Stiggins, R.J. (2001). The unfulfilled promise of classroom assessment. Portland, Oregon: Assessment Training Institute.

Vygotsky, L. (1987) Mind in society: the development of higher psychological processes. Cambridge, Mass.: Harvard University Press.

Wirth, K. and Aziz, F. (2009) 'Better learning through better reading and reflecting', Associated Colleges of the Midwest. Available at http://serc.carleton.edu/acm teagle/projects/wirth.html (Accessed: 14 September 2021).

\section{Author details}

Hana El-Badri is a PhD holder from the University of Aberdeen, School of Education. She is an assistant professor at the Faculty of Languages, University of Benghazi, Libya. Her research interests fall into teaching English as a foreign (EFL), classroom pedagogies, teaching literature in EFL, the role of language in learning, learning conversations and dialogic learning. Her most recent research investigates the use of virtual environments and digital tools in learning. Other research interests include the implementation of technology in the teaching of literature.

Fatma Abu-Baker is Associate tutor in TESOL at the School of Education, University of Glasgow. She obtained her PhD in Educational studies from the university of Glasgow. Her research interests fall under teaching EFL/ESL and has special interests in the teaching of literature in the foreign language classroom, reader-response, and responsebased and arts-based pedagogies. Her recent research investigates how literature, language and technology could be integrated to create meaningful learning spaces and the role of the teacher therein 


\section{Appendix 1: an overview of the worksheet}

\begin{tabular}{|c|c|c|c|}
\hline Parts & Title & Sub parts & Content \\
\hline Part 1 & Background & Cultural content, & $\begin{array}{l}\text { Carnival, amontillado, } \\
\text { catacombs }\end{array}$ \\
\hline Part 2 & Story structure & Development of events & $\begin{array}{l}\text { Beginning, } \\
\text { Plot development, and } \\
\text { type of end }\end{array}$ \\
\hline Part 3 & Language & $\begin{array}{l}\text { Understanding language and } \\
\text { figurative forms }\end{array}$ & $\begin{array}{l}\text { Examples of authentic } \\
\text { language, figurative } \\
\text { language. } \\
\text { Ironic forms. }\end{array}$ \\
\hline Part 3 & $\begin{array}{l}\text { Identifying } \\
\text { characters } \\
\text { Story elements }\end{array}$ & $\begin{array}{l}\text { Protagonist, antagonist, minor } \\
\text { characters, setting }\end{array}$ & \\
\hline Part 4 & $\begin{array}{l}\text { Story overall } \\
\text { understanding }\end{array}$ & $\begin{array}{l}\text { General and thematic meaning. } \\
\text { Relating self for intercultural } \\
\text { awareness }\end{array}$ & \\
\hline Part 5 & Reflection & $\begin{array}{l}\text { - What did you understand } \\
\text { most? Why? } \\
\text { - What supports your } \\
\text { understanding? } \\
\text { - What difficulties did the } \\
\text { worksheet help you to } \\
\text { address? }\end{array}$ & \\
\hline
\end{tabular}




\begin{tabular}{|l|l|l|}
\hline & - What is your major \\
& concern? \\
- & How useful did you find \\
the worksheet? & \\
\hline
\end{tabular}

\section{Appendix 2: learners' reflection on their reading and staff feedback}

\begin{tabular}{|l|l|l|l|l|}
\hline Participants perceived & $\begin{array}{l}\text { Needs for } \\
\text { improvement/staff } \\
\text { view }\end{array}$ & $\begin{array}{l}\text { Participants } \\
\text { views of } \\
\text { improvement }\end{array}$ & $\begin{array}{l}\text { Staff feedback of } \\
\text { improvement }\end{array}$ \\
\hline S1 & $\begin{array}{l}\text { Difficulty in understanding } \\
\text { the main content of the story. }\end{array}$ & $\begin{array}{l}\text { You need to focus } \\
\text { on the paragraphs } \\
\text { and relate the } \\
\text { events. }\end{array}$ & $\begin{array}{l}\text { I was able to } \\
\text { understand } \\
\text { most of events } \\
\text { but still } \\
\text { difficult the } \\
\text { ending. }\end{array}$ & $\begin{array}{l}\text { Show the } \\
\text { beginning of the } \\
\text { learner's self- } \\
\text { reliance. }\end{array}$ \\
\hline S2 & Language and grammar. & $\begin{array}{l}\text { Use should use the } \\
\text { background part to } \\
\text { support your } \\
\text { understanding. }\end{array}$ & $\begin{array}{l}\text { Now, I can } \\
\text { understand } \\
\text { why Fortuntao } \\
\text { killed him. }\end{array}$ & $\begin{array}{l}\text { Development of } \\
\text { understanding the } \\
\text { events. }\end{array}$ \\
\hline S3 & $\begin{array}{l}\text { Problem to understand the } \\
\text { organization of events. }\end{array}$ & $\begin{array}{l}\text { Read about the } \\
\text { story structure in } \\
\text { Part 2 and what the } \\
\text { story is about part, } \\
\text { and skim the } \\
\text { paragraphs. }\end{array}$ & $\begin{array}{l}\text { The pre- } \\
\text { reading } \\
\text { language } \\
\text { make it easier } \\
\text { to understand. } \\
\text { I am also can } \\
\text { understand the } \\
\text { understanding and } \\
\text { ability to negotiate } \\
\text { content of the } \\
\text { parts of the }\end{array}$ & $\begin{array}{l}\text { Shope of ending. } \\
\text { significance of the } \\
\text { pre-reading, }\end{array}$ \\
\hline
\end{tabular}




\begin{tabular}{|c|c|c|c|c|}
\hline & & & $\begin{array}{l}\text { story. The end } \\
\text { cannot } \\
\text { expected. }\end{array}$ & \\
\hline S4 & $\begin{array}{l}\text { Could not understand the } \\
\text { plot. }\end{array}$ & $\begin{array}{l}\text { You need to focus } \\
\text { on the paragraphs } \\
\text { to relate the events } \\
\text { and think critically. }\end{array}$ & $\begin{array}{l}\text { I can say I } \\
\text { understand the } \\
\text { events better. }\end{array}$ & $\begin{array}{l}\text { The beginning of } \\
\text { critical reading. }\end{array}$ \\
\hline S5 & $\begin{array}{l}\text { My major concern is } \\
\text { understanding the events. }\end{array}$ & $\begin{array}{l}\text { Critical reading } \\
\text { and analysis need } \\
\text { to be developed. }\end{array}$ & $\begin{array}{l}\text { Proud of } \\
\text { being able to } \\
\text { answer the } \\
\text { questions. }\end{array}$ & $\begin{array}{l}\text { meaning making } \\
\text { has improved. }\end{array}$ \\
\hline S6 & $\begin{array}{l}\text { Cannot understand the end } \\
\text { and the sequence of action. }\end{array}$ & $\begin{array}{l}\text { Critical evaluation } \\
\text { of the events to } \\
\text { understand the end } \\
\text { of the story. }\end{array}$ & $\begin{array}{l}\text { I used the } \\
\text { worksheet and } \\
\text { cut the story } \\
\text { into chunks to } \\
\text { follow. }\end{array}$ & $\begin{array}{l}\text { Improvement of } \\
\text { understanding the } \\
\text { plot and the } \\
\text { characters. The } \\
\text { students was able } \\
\text { to reflect on the } \\
\text { ending. }\end{array}$ \\
\hline S7 & $\begin{array}{l}\text { The beginning of the story is } \\
\text { not obvious to me with the } \\
\text { following paragraphs. }\end{array}$ & $\begin{array}{l}\text { Use the } \\
\text { background } \\
\text { information and } \\
\text { think critically. }\end{array}$ & $\begin{array}{l}\text { The } \\
\text { instructions in } \\
\text { the worksheet } \\
\text { helped to } \\
\text { proceed } \\
\text { understanding } \\
\text { of the story. }\end{array}$ & $\begin{array}{l}\text { The participant } \\
\text { provided questions } \\
\text { of critical reading } \\
\text { on the text, it } \\
\text { shows } \\
\text { development of } \\
\text { critical analysis } \\
\text { and more self- } \\
\text { independence. }\end{array}$ \\
\hline S8 & $\begin{array}{l}\text { Could not understand using } \\
\text { of some vocabulary and lead }\end{array}$ & $\begin{array}{l}\text { You need to use } \\
\text { the background } \\
\text { information, think }\end{array}$ & $\begin{array}{l}\text { The story is } \\
\text { clearer when I } \\
\text { used the }\end{array}$ & $\begin{array}{l}\text { The student's } \\
\text { answers show }\end{array}$ \\
\hline
\end{tabular}




\begin{tabular}{|c|c|c|c|c|}
\hline & $\begin{array}{l}\text { me to not understand the } \\
\text { whole story. }\end{array}$ & $\begin{array}{l}\text { critically to relate } \\
\text { the events. }\end{array}$ & $\begin{array}{l}\text { worksheet } \\
\text { questions. }\end{array}$ & $\begin{array}{l}\text { development in } \\
\text { understanding. }\end{array}$ \\
\hline S9 & $\begin{array}{l}\text { My big difficulty is the words } \\
\text { and the grammar in the story }\end{array}$ & $\begin{array}{l}\text { You need to } \\
\text { consider figurative } \\
\text { language forms } \\
\text { used in the text. }\end{array}$ & $\begin{array}{l}\text { I can know } \\
\text { irony used, it } \\
\text { was difficult } \\
\text { to understand } \\
\text { the story } \\
\text { without } \\
\text { finding the } \\
\text { irony }\end{array}$ & $\begin{array}{l}\text { Attempts for } \\
\text { understanding the } \\
\text { figurative forms } \\
\text { led to } \\
\text { development in } \\
\text { meaning making. }\end{array}$ \\
\hline S10 & $\begin{array}{l}\text { It was hard to understand the } \\
\text { events correct }\end{array}$ & $\begin{array}{l}\text { You need to read } \\
\text { critically. }\end{array}$ & $\begin{array}{l}\text { I get they } \\
\text { went to } \\
\text { catacombs but } \\
\text { he killed him? }\end{array}$ & $\begin{array}{l}\text { It shows how the } \\
\text { learner developed } \\
\text { understanding but } \\
\text { scaffolding } \\
\text { required. }\end{array}$ \\
\hline S11 & $\begin{array}{l}\text { Meaning of metaphors and I } \\
\text { also find the plot is difficult. }\end{array}$ & $\begin{array}{l}\text { Identify the } \\
\text { figurative forms } \\
\text { correctly and read } \\
\text { critically. }\end{array}$ & $\begin{array}{l}\text { Not easy to } \\
\text { find the form } \\
\text { but I can say } \\
\text { the end } \\
\text { becomes } \\
\text { clear. }\end{array}$ & $\begin{array}{l}\text { Shows beginning } \\
\text { of independent } \\
\text { reading but more } \\
\text { scaffolding } \\
\text { required. }\end{array}$ \\
\hline S12 & $\begin{array}{l}\text { Grammar of the story and the } \\
\text { organization of paragraphs. }\end{array}$ & $\begin{array}{l}\text { Use the } \\
\text { background } \\
\text { information and } \\
\text { read the text } \\
\text { critically. }\end{array}$ & $\begin{array}{l}\text { Yes, I } \\
\text { understand the } \\
\text { text clear with } \\
\text { the parts in the } \\
\text { sheet. }\end{array}$ & $\begin{array}{l}\text { Improved } \\
\text { understanding the } \\
\text { events, better } \\
\text { answers and clear } \\
\text { focus on the } \\
\text { figurative forms }\end{array}$ \\
\hline S13 & $\begin{array}{l}\text { I could not proceed with } \\
\text { events development. }\end{array}$ & $\begin{array}{l}\text { Critical reading } \\
\text { requires you to }\end{array}$ & $\begin{array}{l}\text { The worksheet } \\
\text { was the } \\
\text { skeleton I }\end{array}$ & $\begin{array}{l}\text { The worksheet has } \\
\text { been used } \\
\text { correctly to relate }\end{array}$ \\
\hline
\end{tabular}




\begin{tabular}{|c|c|c|c|c|}
\hline & & $\begin{array}{l}\text { provide clues and } \\
\text { to report questions. }\end{array}$ & $\begin{array}{l}\text { build on my } \\
\text { understanding. }\end{array}$ & $\begin{array}{l}\text { events and to } \\
\text { identify figurative } \\
\text { forms. This second } \\
\text { version is much } \\
\text { better than the } \\
\text { first. }\end{array}$ \\
\hline S14 & $\begin{array}{l}\text { Difficult to relate the events } \\
\text { in the story. }\end{array}$ & $\begin{array}{l}\text { Critical } \\
\text { questioning is } \\
\text { required while } \\
\text { reading the story. }\end{array}$ & $\begin{array}{l}\text { The } \\
\text { conclusion } \\
\text { and the } \\
\text { second and } \\
\text { the third } \\
\text { paragraphs } \\
\text { became clear } \\
\text { to me. }\end{array}$ & $\begin{array}{l}\text { Used the } \\
\text { worksheet } \\
\text { effectively to work } \\
\text { on the structure of } \\
\text { the text. }\end{array}$ \\
\hline S15 & $\begin{array}{l}\text { I cannot understand the } \\
\text { words and cannot understand } \\
\text { the events. }\end{array}$ & $\begin{array}{l}\text { You still need to } \\
\text { use the background } \\
\text { information and } \\
\text { make more critical } \\
\text { questioning. }\end{array}$ & $\begin{array}{l}\text { I understand } \\
\text { the end. }\end{array}$ & $\begin{array}{l}\text { Some } \\
\text { improvements } \\
\text { made to the first } \\
\text { version. }\end{array}$ \\
\hline S16 & $\begin{array}{l}\text { I find difficult to understand } \\
\text { the events follow and the end } \\
\text { is not clear to me. }\end{array}$ & $\begin{array}{l}\text { To answer the } \\
\text { questions correctly, } \\
\text { more critical } \\
\text { evaluation is } \\
\text { required. }\end{array}$ & $\begin{array}{l}\text { I feel I bring } \\
\text { the events } \\
\text { together }\end{array}$ & $\begin{array}{l}\text { Events well } \\
\text { understood. } \\
\text { Positive changes } \\
\text { made to the } \\
\text { version following } \\
\text { the instructions of } \\
\text { the worksheet. }\end{array}$ \\
\hline S17 & $\begin{array}{l}\text { The structure of the story is } \\
\text { not clear. }\end{array}$ & $\begin{array}{l}\text { You need to utilize } \\
\text { your critical } \\
\text { evaluation. }\end{array}$ & $\begin{array}{l}\text { I followed the } \\
\text { story better }\end{array}$ & $\begin{array}{l}\text { Used the } \\
\text { worksheet quite } \\
\text { effectively for } \\
\text { better meaning }\end{array}$ \\
\hline
\end{tabular}




\begin{tabular}{|c|c|c|c|c|}
\hline & & & & $\begin{array}{l}\text { making of the } \\
\text { story. }\end{array}$ \\
\hline 18 & $\begin{array}{l}\text { Connect the events is } \\
\text { difficult. }\end{array}$ & $\begin{array}{l}\text { Make use of } \\
\text { critical questioning } \\
\text { while reading, keep } \\
\text { focused and relate } \\
\text { precise events. }\end{array}$ & $\begin{array}{l}\text { I was able to } \\
\text { integrate the } \\
\text { guidelines in } \\
\text { my reading. }\end{array}$ & $\begin{array}{l}\text { The second } \\
\text { version has } \\
\text { improved } \\
\text { significantly from } \\
\text { the first draft, } \\
\text { making inferences } \\
\text { for meaning } \\
\text { making. The } \\
\text { worksheet is used } \\
\text { effectively. }\end{array}$ \\
\hline S19 & $\begin{array}{l}\text { Language, tenses, some } \\
\text { vocabulary like as } \\
\text { amontillado }\end{array}$ & $\begin{array}{l}\text { Use the } \\
\text { background part, } \\
\text { make inferences } \\
\text { and question } \\
\text { critically. }\end{array}$ & $\begin{array}{l}\text { I think the } \\
\text { flow of the } \\
\text { events is } \\
\text { clearer }\end{array}$ & $\begin{array}{l}\text { You have worked } \\
\text { on providing } \\
\text { better } \\
\text { understanding of } \\
\text { the text following } \\
\text { the worksheet }\end{array}$ \\
\hline
\end{tabular}

